УДК 004.413.4; 504.05; 614.8

\title{
МОДЕЛЮВАННЯ ТА КІЛЬКІСНЕ ОЦІНЮВАННЯ СОЦІАЛЬНОГО РИЗИКУ У КОНТЕКСТІ ПЛАНОВАНОЇ ДІЯЛЬНОСТІ ПІДПРИЕМСТВОМ ДЕРЕВООБРОБНОЇ ПРОМИСЛОВОСТІ В С. ГОРОДОК, РІВНЕНСЬКОЇ ОБЛАСТІ
}

\author{
Д.В. Стефанишин ${ }^{1}$, Д.Е. Бенатов² \\ ${ }^{1}$ Інститут телекомунікацій і глобального інформаційного простору НАН Украйни \\ Чоколівський б-вар, 13, Київ, 03186, Україна \\ ${ }^{2}$ Національний технічний університет Украӥни \\ «Київський політехнічний інститут ім. Ігоря Сікорського» \\ пр. Перемоги, 37, Київ, 03056, Україна \\ e-mail: d.v.stefanyshyn@gmail.com
}

Серед обов'язкової інформації, яка згідно з Законом України «Про оцінку впливу на довкілля» [1] має включатися в звіт з оцінки впливу на довкілля (ОВД), окремим розділом у звіті проходить «опис і оцінка можливого впливу на довкілля планованої діяльності, зокрема величини та масштабів такого впливу (площа території та чисельність населення, які можуть зазнати впливу), ...», у зв’язку, в тому числі, з «ризиками для здоров’я людей».

Завдання з кількісного оцінювання ризику для здоров’я людей є складним завданням $[2,3]$. Адекватне його вирішення потребує не лише високопрофесійних умінь, а і прозорості в оцінках, щоб не допускати різного роду маніпуляцій та перекручень [2]. Зважаючи на складність і різноманітність задач кількісного оцінювання ризику життєдіяльності [4-8], на практиці, зокрема в процесах ОВД, зазвичай використовують спрощені формалізовані підходи та моделі, що грунтуються на використанні статистичних даних та різного роду припущень. Зокрема, такий підхід до оцінювання ризику для здоров'я населення від забруднення атмосферного повітря знайшов своє відображення в Методичних рекомендаціях [9], розроблених Міністерством охорони здоров'я (MO3) України і затверджених Наказом МО3 України від 13.04.2007 №184.

Потребі в об’єктивному кількісному оцінюванні ризиків слід завдячувати страхуванню [2, 10-12]. Саме через прийнятність для практичного використання кількісних оцінок ризиків в роботі провідних страхових фірм, які спеціалізуються на ризику в своїй господарській діяльності, слід розглядати їх адекватність і коректність. Однак, Закон [1] не зобов'язує розробників ОВД «верифікувати» отримані оцінки ризику для життя і здоров'я людини його страхуванням (як добровільного або професійного ризику, так і недобровільного ризику - для населення, яке проживає в зоні потенційних впливів небезпечних виробництв).

Втім, існує кілька загальних принципів, виконання яких сприяє забезпеченню коректності і адекватності оцінювання ризику незалежно від форми його представлення.

Особливе значення при кількісному оцінюванні ризику може мати контекст поставленої задачі. Якщо, наприклад, мова йде про порівняння альтернатив за ризиком, з вибором серед них найменш ризикованої, то, насамперед, важливо забезпечити врахування всіх факторів 
ризику, властивих альтернативам, об'єктивність даних, які їх описують, та використовувати однакові підходи, методи і моделі при оцінюванні ризиків, пов'язаних з альтернативами [13].

При оцінюванні ризику (при його прогнозуванні) в якості вихідних даних зазвичай використовуються статистичні (ретроспективні) дані. В багатьох випадках ці дані слугують i базою для калібрування вибраних моделей ризику та його оцінювання шляхом екстраполяцій $[2,14,15]$, і від того, наскільки повно і коректно дані використовуються може залежати адекватність прогнозних оцінок ризику [16]. Статистичні оцінки часто слугують і в якості основи для верифікації ризиків, отриманих аналітичними методами [16].

Результати оцінювання ризику різними методами, на основі різних моделей, отримані за однакових умов, можуть різнитися, в тому числі і суттєво $[15,16]$. Однак, якщо кількісне оцінювання ризику здійснюється різними дослідниками одним і тим же методом, то отримані при цьому різні значення ризику можуть вказувати на некоректність розв'язання задачі одним 3 дослідників, маніпуляцію вхідними даними тощо.

Метою наших досліджень був аналіз адекватності результатів кількісного оцінювання соціального ризику, пов'язаного з роботою підприємства деревообробної промисловості в с. Городок, Рівненського району, Рівненської області, які було представлено в звіті з оцінки впливу на довкілля (ОВД) планованої діяльності «Реконструкція промислового комплексу будівель і споруд під підприємство деревообробної промисловості за адресою: Рівненська область, Рівненський район, с. Городок, вул. Барона Штейнгеля, 4а» (номер справи 20198144297) [17]. Оцінки соціального ризику було отримано згідно Рекомендацій [9]. Альтернативні розрахунки ризику, з метою порівняння результатів, здійснювалися за тими ж залежностями, наведеними в [17], при тих же значеннях площі, віднесеної під об'єкт планованої діяльності, та площі об'єкта з санітарно-захисною зоною, а також при тих же розрахункових концентраціях канцерогенних речовин, а також 3 врахуванням тих же забруднюючих речовин, здатних викликати канцерогенні ефекти, встановлених в [17].

Соціальний ризик $R_{S}$, чол./рік, визначався як «ризик групи людей, на яку може вплинути впровадження об'єкта планованої діяльності, та особливостей природно-техногенної системи» $[9,17]$ з врахуванням канцерогенних ефектів від забруднюючих речовин:

$$
R_{S}=C R_{a} \cdot V_{u} \cdot \frac{N}{T} \cdot\left(1-N_{p}\right)
$$

де $C R_{a}$ - індивідуальний канцерогенний ризик від комбінованої дії декількох канцерогенних речовин, що забруднюють атмосферу; $V_{u}$ - уразливість території до забруднення атмосферного повітря (відношення площі, віднесеної під об'єкт планованої діяльності, до площі об'єкта з санітарно-захисною зоною); $N$ - чисельність населення, що ризикує внаслідок планованої діяльності, чол.; $T$ - середня тривалість життя у соціумі, роки; $N_{p}$ - коефіцієнт зайнятості для планованої діяльності (відношення кількості додаткових робочих місць $N_{a}$, чол., до чисельності населення $N$, чол., що ризикує: $N_{p}=N_{a} / N_{\text {). }}$

Значення канцерогенного ризику $C R_{a}$ оцінювалось згідно формули:

$$
C R_{a}=\sum_{i} I C R_{i}
$$

де $I C R_{i}$ - канцерогенний ризик для $i_{-}$ї канцерогенної речовини:

$$
I C R_{i}=C_{i} \cdot U R_{i}
$$




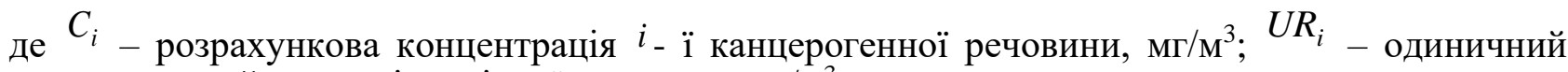
канцерогенний ризик відповідної речовини, мг/ $\mathbf{M}^{3}$ :

$$
U R_{i}=\frac{S F_{i}}{M_{b} \cdot W_{a}},
$$

де $S F_{i}$ - фактор канцерогенного потенціалу, який встановлювався згідно з додатком до п. 4.3.2 Методичних рекомендацій [9], в залежності від забруднюючої речовини, мг/кг·доба; $M_{b}$ розрахункова маса тіла людини, що ризикує внаслідок планованої діяльності, кг; $W_{a}$ розрахункове значення добового споживання нею повітря, ${ }^{3}$.

Соціальний ризик планованої діяльності оцінювався 3 врахуванням дії наступних забруднюючих речовин: формальдегід; хром шестивалентний; бенз(а)пірен (табл. 1).

Таблиця 1.

Загальна характеристика канцерогенного потенціалу забруднюючих речовин від планованої діяльності, визначених в $[9,17]$ як такі, що здатні викликати канцерогенні ефекти

\begin{tabular}{|l|c|c|}
\hline \multicolumn{1}{|c|}{ Речовина } & $\begin{array}{c}\text { Розрахункова концентрація, } \\
C_{i}, \mathrm{Mг} / \mathrm{m}^{3}[17]\end{array}$ & $\begin{array}{c}\text { Фактор } S F_{i}, \text { мг/кг·доба } \\
{[9]}\end{array}$ \\
\hline Формальдегід & 0,01688 & 0,046 \\
\hline Хром шестивалентний & 0,000000413 & 42 \\
\hline Бенз(а)пірен & 0,000003 & 3,1 \\
\hline
\end{tabular}

Площа території, віднесеної під об’єкт планованої діяльності, та площа об'єкта з санітарнозахисною зоною були прийняті рівними, відповідно: $640000 \mathrm{~m}^{2}$ та $710650 \mathrm{~m}^{2}$. Коефіцієнт уразливості території до забруднення атмосферного повітря $V_{u}=0,9$. Інші вихідні дані, що використовувались при оцінюванні соціального ризику планованої діяльності, для зручності порівняння значень, прийнятих в [17] та при проведених нами альтернативних розрахунках соціального ризику, представлено нижче в табл. 2.

Таблиця 2.

Дані для кількісного оцінювання соціального ризику планованої діяльності

\begin{tabular}{|l|c|c|c|}
\hline \multirow{2}{*}{ Найменування характеристики } & \multicolumn{3}{|c|}{ Числові значення характеристик } \\
\cline { 2 - 4 } & $\begin{array}{c}\text { Звіт 3 } \\
\text { ОВД [17] }\end{array}$ & \multicolumn{2}{|c|}{ Дльтернативні розрахунки } \\
\hline $\begin{array}{l}\text { Чисельність населення, що } \\
\text { ризикує, } N \text {, чол. }\end{array}$ & $2719 *$ & $5348 * *$ & 2000-25000*** \\
\hline $\begin{array}{l}\text { Середня тривалість життя } T, \\
\text { роки }\end{array}$ & 70 & 70 & 70 \\
\hline $\begin{array}{l}\text { Чисельність додаткових робочих } \\
\text { місць } N_{a}\end{array}$ & 400 & $200 * * * *$ & Фактор не враховується \\
\hline
\end{tabular}


Продовження табл. 2

\begin{tabular}{|l|c|c|c|}
\hline $\begin{array}{l}\text { Коефіцієнт зайнятості для } \\
\text { планованої діяльності } N_{p}\end{array}$ & 0,147 & 0,037 & 0 \\
\hline $\begin{array}{l}\text { Розрахункова маса тіла людини } \\
M_{b}, \text { кг }\end{array}$ & $70 * * * * *$ & $60 * * * * * *$ & 60 \\
\hline $\begin{array}{l}\text { Споживання повітря людиною } \\
W_{a}, \mathrm{M}^{3} / \text { доба }\end{array}$ & 20 & 20 & 20 \\
\hline $\begin{array}{l}\text { Індивідуальний канцерогенний } \\
\text { ризик } C R_{a}\end{array}$ & $5,7 \cdot 10^{-7}$ & $6,7 \cdot 10^{-7}$ & $6,7 \cdot 10^{-7}$ \\
\hline
\end{tabular}

* чисельність населення с. Городок, прийнята в [17], що відповідає даним Вікіпедії;

** чисельність населення с. Городок згідно листа Управління охорони здоров'я при Рівненській обласній державній адміністрації (УОЗ РОДА), надісланого на запит депутата Рівненської міської ради І.С. Пилипчук від 11.01.2020 р.;

*** в тому числі з врахуванням можливого впливу на жителів інших населених пунктів, розташованих поблизу площадки планованої діяльності;

**** озвучена на громадських обговореннях звіту з ОВД [17] кількість безпосередніх працівників підприємства; ***** «стандартна» маса дорослого чоловіка;

****** розрахункова маса тіла людини, рекомендована в якості фактора експозиції Всесвітньою організацією охорони здоров'я (ВОО3) [9].

Чисельність додаткових робочих місць $N_{a}$, як фактор, що згідно з Рекомендаціями [9] «понижує» соціальний ризик від забруднення атмосферного повітря (для канцерогенних ефектів) внаслідок планованої діяльності, при альтернативних розрахунках ризику (імітаційному моделюванні) нами не враховувалась з наступних міркувань.

1. Модель (1) (для канцерогенних ефектів) припускає, що зайнятість на підприємстві, діяльність якого пов'язана 3 забрудненням атмосферного повітря, здатна зменшувати соціальний ризик для місцевих жителів. Таке припущення може вважатися коректним лише у випадку, коли місцеві жителі, які працюють на підприємстві, не потерпають від дії забруднюючих речовин (працюють і живуть в іншому місці).

2. Канцерогенний ризик $C R_{a}$ для працівників підприємства, діяльність якого пов'язана 3 забрудненням атмосферного повітря (для канцерогенних ефектів), зазвичай є більшим, ніж для представників місцевого населення тієї ж соціальної групи (наприклад, для дорослих чоловіків). Єдине, що реально відрізняє ці дві групи - це поведінкове ставлення до ризику. Для працівників ризик вважається добровільним, для місцевих жителів, що не є працівниками підприємства, - може бути недобровільним (насправді і є саме таким).

3. Модель $R_{S}(1)$ припускає, що використання в якості робочої сили на підприємстві, яке забруднює атмосферне повітря (з канцерогенними ефектами), всього населення, що ризикує внаслідок цієї діяльності (включно малолітніх дітей, непрацездатних тощо), може звести відповідний соціальний ризик до нуля, що, звичайно, не так.

При оцінці допустимості соціального ризику та 3 метою верифікації результатів оцінювання соціального ризику планованої діяльності до уваги приймалися також статистичні дані щодо захворюваності на онкологічні хвороби жителів для с. Городок та для подібних за кількістю мешканців сіл Рівненського району, розташованих на околиці м. Рівне: с. Колоденка (на південний схід від міста) та с. Біла Криниця (на схід від міста). Поблизу цих сіл, на відміну від с. Городок, біля якого вже працює підприємство хімічної промисловості (ПАТ «Рівнеазот» 
OSTCHEM), подібні підприємства відсутні. Дані наведено в табл. 3. Кількісні характеристики захворюваності було надано листом УОЗ РОДА, підписаним заступником начальника управління І.Я. Добровольським, за запитом депутата Рівненської міської ради І.С. Пилипчук від 11.01.2020 p.

Таблиця 3.

\section{Статистичні дані щодо захворюваності на онкологічні хвороби жителів сіл Рівненського району}

\begin{tabular}{|c|c|c|c|}
\hline \multirow[b]{2}{*}{$\begin{array}{c}\text { Населений } \\
\text { пункт }\end{array}$} & \multicolumn{2}{|c|}{ Дані УОЗ РОДА } & \multirow{2}{*}{$\begin{array}{c}\text { Статистична оцінка соціального ризику } \\
\text { захворюваності на онкологічні хвороби } \\
\qquad \hat{R}_{S} \text {, чол./рік }\end{array}$} \\
\hline & $\begin{array}{c}\text { Кількість } \\
\text { жителів } \\
N, \text { чол. }\end{array}$ & $\begin{array}{c}\text { Кількість } \\
\text { онкохворих } \\
n, \text { чол. }\end{array}$ & \\
\hline с. Городок & 5348 & 40 & $1,1 \cdot 10^{-4}$ \\
\hline с. Колоденка & 4870 & 33 & $9,7 \cdot 10^{-5}$ \\
\hline с. Біла Криниця & 7185 & 52 & $10^{-4}$ \\
\hline
\end{tabular}

В звіті з ОВД [17] була розрахована і оприлюднена оцінка соціального ризику планованої діяльності $R_{S}=1,7 \cdot 10^{-5}$, чол./рік. Ця оцінка порівнювалася 3 допустимими значеннями для різних рівнів соціального ризику, визначених як [17]: «прийнятний» (менше 10-6, чол./рік); «умовно прийнятний» $\left(10^{-4} \div 10^{-6}\right.$, чол./рік); «прийнятний для професійних контингентів $\mathrm{i}$ неприйнятний для населення» $\left(10^{-3} \div 10^{-4}\right.$, чол./рік); «неприйнятний для професійних контингентів» (більше ніж $10^{-3}$, чол./рік). Відповідно, соціальний ризик для населення с. Городок від забруднення атмосферного повітря (для канцерогенних ефектів протягом життя людини) внаслідок планованої діяльності було визнано як «умовно прийнятний».

За проведеними нами альтернативними розрахунками для с. Городок (див. дані табл. 2) була отримана оцінка $R_{S}=4,4 \cdot 10^{-5}$, чол./рік, яка майже в 2,6 рази перевищує наведену в [17] оцінку $R_{S}=1,7 \cdot 10^{-5}$, чол./рік, хоча вона і відповідає «умовно прийнятному» рівню ризику.

В зв'язку з тим, що статистична оцінка соціального ризику (див. табл. 3) захворюваності на онкологічні хвороби для с. Городок за даними на 2020 р., $\hat{R}_{S}=1,1 \cdot 10^{-4}$, чол./рік, виявилася значно вищою отриманих розрахункових значень ризику $\left(1,7 \cdot 10^{-5}\right.$ та $4,4 \cdot 10^{-5}$, чол./рік) i «неприйнятною для населення», і зважаючи на те, що соціальний ризик може зростати зі збільшенням кількості тих, хто ризикує, нами було проведено імітаційне моделювання соціального ризику з врахуванням потенційно можливого впливу планованої діяльності на жителів і інших населених пунктів, що оточують площадку майбутнього підприємства.

Результати імітаційного моделювання соціального ризику наведено нижче на рисунку. Виділено дві криві соціального ризику: за результатами виконаних альтернативних розрахунків (зокрема, без врахування зайнятості); криву соціального ризику, яка відповідає даним звіту з ОВД [17] (в тому числі з врахуванням зайнятості для 400 осіб). 


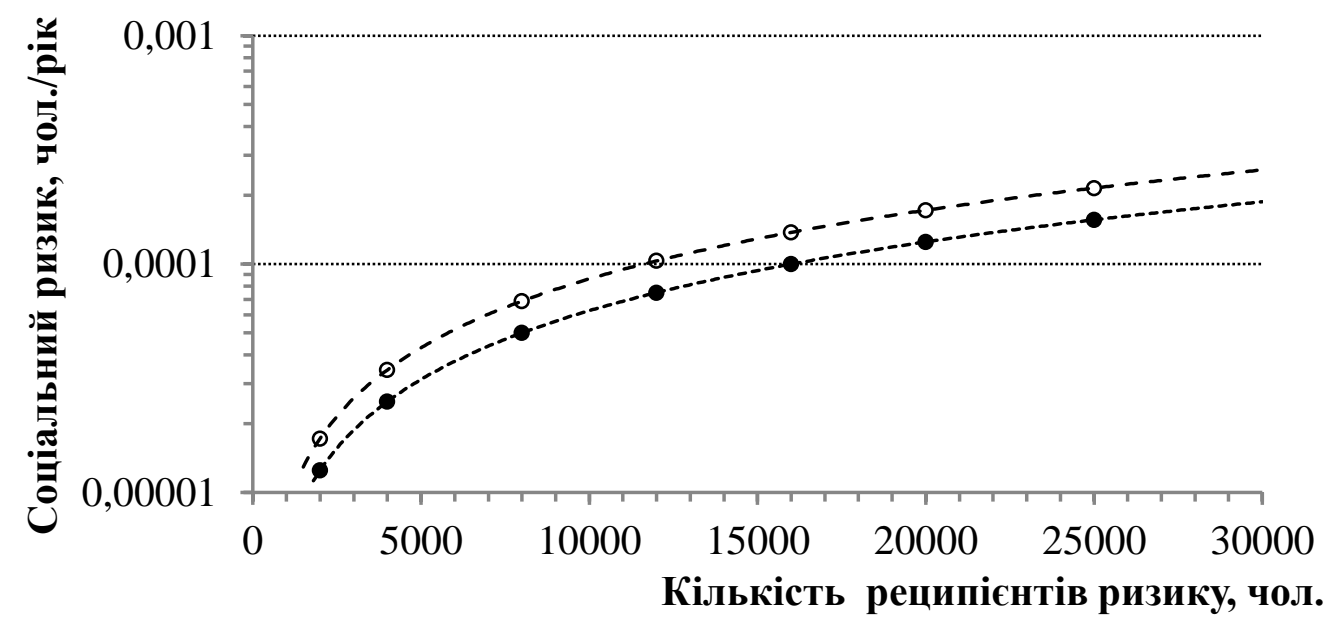

○ Альтернативні розрахунки • Розрахунки згідно даних звіту з ОВД [17]

\section{Рисунок. Криві соціального ризику планованої діяльності за результатами імітаційного моделювання}

Результати імітаційного моделювання соціального ризику планованої діяльності (див. рисунок) показали, що його значення $10^{-4}$, чол./рік, «прийнятне для професійних контингентів і неприйнятне для населення», встановлюється при кількості осіб, що ризикують, від 12000 (при розрахунковій масі тіла людини $M_{b}=60$ кг та без врахування зайнятості) до $16000\left(M_{b}\right.$ $=70$ кг та з врахуванням зайнятості при кількості 400 працюючих на підприємстві з місцевих жителів). При цьому чисельність жителів лише трьох розташованих поблизу підприємства сіл (Городок, Обарів, Великий Олексин) можна оцінити щонайменше в 12-16 тисяч. 3 врахуванням жителів прилеглого до підприємства мікрорайону «Ювілейний» м. Рівне та жителів ще кількох сіл (Ставки, Понебель, Карпилівка) загальна кількість населення, що ризикуватиме внаслідок викидів підприємства може перевищити 25000. Отже, від того, наскільки коректно буде встановлено чисельність населення, на яке впливатиме діяльність підприємства, залежить чесність, прозорість і неупередженість його оцінювання. Слід також зазначити, що ризики, що аналізувалися, встановлювалися лише для штатних умов роботи підприємства. Для більш глибокого вивчення проблеми слід провести дослідження соціального ризику планованої діяльності із врахуванням надзвичайних ситуацій, пов'язаних 3 аварійними викидами внаслідок аварій на підприємстві.

\section{Література:}

1. Про оцінку впливу на довкілля: Закон України № 2059-VIII від 23.05.2017. Офіційний вісник України. 2017. №50. С. 5. Відомості Верховної Ради (ВВР), 2017, № 29, ст. 315. Retrieved from http://zakon.rada.gov.ua/laws/show/2059-19.

2. Bernstein P.L. Against the Gods: The Remarkable Story of Risk. Published by J. Wiley \& Sons, Inc. N.Y. 1996. 369 p.

3. Rowe W. An anatomy of risk. Published by W. J. Wiley \& Sons, Inc. N.Y. 1997. 488 p.

4. Kumamoto H., Henley E.J. Probabilistic risk assessment and management for engineers and scientists. N.Y.: IEEE Press, 1996. 597 p. 
5. Качинський А.Б. Безпека, загрози і ризик: наукові концепції та математичні методи: монографія. Ін-т проблем національної безпеки. Нац. акад. служби безпеки України. Київ : [б. н.], 2004. $470 \mathrm{c.}$

6. Шапкин А.С., Шапкин В.А. Теория риска и моделирование рисковых ситуаций. Москва: Издательско-торговая корпорация «Дашков и $\mathrm{K}^{0} », 2005.880 \mathrm{c.}$

7. Биченок М.М., Иванюта С.П., Яковлев Є.О. Ризики життєдіяльності у природнотехногенному середовищі. Київ : Інститут проблем національної безпеки, 2008. 160 с.

8. Лисиченко Г.В., Забулонов О.Л., Хміль Г.А. Природний, техногенний та екологічний ризики: аналіз, оцінка, управління. Київ : Наукова думка, 2008. 544 с.

9. Методичні рекомендації МР 2.2.12-142-2007. Оцінка ризику для здоров'я населення від забруднення атмосферного повітря. Затверджено наказом МОЗ України від 13.04.07 р., № 184 . Retrieved from http://online.budstandart.com/ua/catalog/doc-page.html?id_doc=26866.

10. Справочник по страхованию в промышленности. [Пер. с нем. Под ред. Н.А. Никологородского]. Москва: Страховой полис, ЮНИТИ, 1994.

11. Dionne G. Ed. Handbook of Insurance. Kluwer Academic Publishers. 2000. 1119 p.

12. Insurance Handbook. A guide to insurance: what it does and how it works. Insurance Information Institute. New York. 2010. 195 p.

13. Стефанишина-Гаврилюк Ю.Д., Стефанишин Д.В. Прийняття рішень у природокористуванні 3 урахуванням ризику невикористаних можливостей на підставі попарного порівняння альтернатив. Системні дослідження та інформаційні технології. 2016. №3. C. 51-62.

14. Taleb N.N. The Black Swan. The Impact of the Highly Improbable. Second enlarged edition. Random House. New York, 2010. 480 p.

15. Стефанишин Д.В. Вибрані задачі оцінки ризику та прийняття рішень за умов стохастичної невизначеності. Київ : Азимут-Україна, 2009. 104 с.

16. Stefanyshyn D.V. On the use of the type I Gumbel distribution to assess risks given floods. Математичне моделювання в економіці. №1, 2018. С. 74-83.

17. Єдиний реєстр з оцінки впливу на довкілля. Товариство з обмеженою відповідальністю «Технопривід Інвест Груп» Рівненська обл., Рівненський р-н, с. Городок, вул. Барона Штейнгеля, 4a (номер реєстраційної справи 20198144297). Retrieved from http://eia.menr.gov.ua/uk/cases?number=20198144297. 